\title{
MINTÁK ÉS MÓDSZEREK
}

\author{
A HETVENES ÉVEK HAZAI ÉPÍTÉSZETE ÉS A KARAKTER*
}

\author{
SIMON MARIANN**
}

\begin{abstract}
A hetvenes évek hazai építészete - az összképet tekintve - fölöttébb unalmas benyomást kelt. A szocializmus építésének lendületét az átadott épületek légköbmétereiben mérve, a rendszer teljesítményének maximumát nyújtotta, miközben éppen a megnövekedett építési volumen következtében egyre nyilvánvalóbbá váltak a modern építészet ellentmondásai. Az állami lakásépítés 1975-ben érte el csúcspontját, ekkor adták át az egymilliomodik lakást, s ezzel a harmincadik évfordulóra teljesült a 15 éves lakásépítési terv. Látszólag minden rendben volt, mégsem volt egyöntetű az elégedettség. A lakótelepek szürkék és sivárak voltak, egyforma magas, hasáb alakú épületekkel, lyukablakokkal és megtalálhatatlan bejáratokkal. A tömbök a semlegesen szétfolyó térben úsztak, hiányoztak az utcák, a terek, a tájékozódási pontok. A középületekben sem tükröződött több fantázia, akár új, akár régi környezetben épültek. A többnyire a torony és a lepény egyszerü kontrasztjára szerkesztett házak terveikben nélkülözték az építészeti átgondoltságot, kivitelezésükben viszont tükrözték az építőipar alacsony színvonalát.

A lakótelepek monotonitását és a környezet jellegtelenségét ekkor már szóvá lehetett tenni - igaz, nem akárhol és nem akárkinek. A napilapokban legfeljebb egy müvész írhatta le, hogy a Kelenföldi lakótelep „,nem szervült a város építészetileg tarka jellegéhez, s mint egy kiátkozott vagy szándékosan elkülönült kísérleti telep, élettelennek mutatkozott szürkeségében" - mint tette azt Bernáth Aurél 1973-ban. ${ }^{1}$ 1975-ben Nagy László már keményebben fogalmazott: „Mintha tizedrangú zord és üzleties Bauhaus-betonbanya tojta volna tele ivadékaival hazánkat”, ${ }^{2}$ de Görgey Gábor sem kímélte a modern épített környezetet és az építészeket

* A tanulmány az OTKA T-024029 számú kutatása keretében készült.

** Budapesti Műszaki és Gazdaságtudományi Egyetem, Építészettörténeti és Műemléki Tanszék. 1111 Budapest, Müegyetem rkp. 3. K. II. 60. Fax: 463-1638; e-mail: simmar@eszd.bme.hu

${ }^{1}$ Bernáth Aurél: Építészeti kalandozások. Magyar Nemzet, 1973. november 7.

${ }^{2}$ Nagy László: Hol a tulipán? Élet és Irodalom, 1975. október 4.
\end{abstract}


1977-es írásában. ${ }^{3}$ A nagyközönség számára közvetített hivatalos vélemény azonban az volt, hogy „nem a panelban van a hiba”, ${ }^{4}$ s mivel a tömeges építésnek nincs más útja, mint a házgyári, az adott rendszeren belül kell kiküszöbölni a tagadhatatlan egyhangúságot.

Kritizálhatták a helyzetet az építészek is, saját belső, szakmai fórumaikon. A lakótelepek esztétikai hiányosságát említve, 1973-ban, a Magyar Építőmúvészetben le lehetett írni, hogy ,a város használója, a benne járó, élő ember nem kap sem vizuális, sem funkcionális értelemben élményt", 5 s javaslatokat is lehetett tenni a lakótelepi környezet javítására. Tereket és utcákat kellene létrehozni, kisebb, megkülönböztethető egységekben és folyamatos, lépesenkénti építésben gondolkozni, figyelembe véve a mủvi és a természeti környezet adottságait, sőt esetleg a lakók aktív részvételével is számolni. A lakótelep-építést megújító - a rövid cikktől a tanulmányig terjedő, sokszor központilag tematizált ${ }^{6}$ - írásoknak két korláttal biztosan kellett számolniuk: az egyik a paneles építés követelménye, a másik a modern építészet tabuja volt. Előbbi korlátot a politika és az építőipar, utóbbit a hazai építészetelmélet állította.

A modern építészet revíziója nemzetközileg már a hatvanas évek közepén megkezdődött, s tíz évvel később a nyugat szinte túl volt a modernen, amikor nálunk még mindig a klasszikus modernizmus, a Bauhaus-idea volt a hivatalos etalon. ${ }^{7} \mathrm{~A}$ modernizmuson túllépni így az elmélet felől nem, legfeljebb a gyakorlat felől lehetett, amit viszont a praxis gazdasági és technikai kötöttsége nehezített. Az 1968-as gazdasági mechanizmussal mégis elindult valami, aminek az 1972-es politikai fordulat sem tudott gátat vetni. ${ }^{8}$ A bomlás és az alternatívák keresése a hetvenes évek elején nálunk is megkezdődött, de a kérdések és a válaszok nyílt megfogalmazására csak később, akkor is csak egy szúkebb nyilvánosságban került sor.

${ }^{3}$ Görgey Gábor: Pardon. Magyar Nemzet, 1977. szeptember 25.

${ }^{4}$ Keserü Ernő: Nem a panelben van a hiba. Magyar Nemzet, 1976. május 23.

${ }^{5}$ Szokolay Örs: Néhány gondolat építészeti környezetünkről. Magyar Épitömüvészet, 1973. 4.

${ }^{6}$ A Fiatal Építészek Köre III. ciklusának hallgatói 1974 és 1976 között például olyan központilag felajánlott kidolgozandó témák közül választhattak, mint „A házgyári lakásépítés fejlesztési lehetőségei”, „Igények és lehetőségek a házgyári lakások használati értéknöveléséhez”, vagy „A paneles építési módnak a tömeges lakásépítésen kívüli tervezési lehetőségei.” Magyar Épitőmüvészet, 1977. 3.

7 „Tervezésünk szakmai minőségével még mindig komoly bajok vannak ... E bajok abból is származnak, hogy építészetünkben a szemléletünk szerint ma is érvényesnek tartott elveket és módszert, az új építészet elveit - elméletét - és módszerét nem alkalmazzák megfelelően, nem használják fel kellőképpen a tervek helyességének ellenőrzésére" - állapította meg Major Máté, a kor vezető teoretikusa itt és minden más lehetséges fórumon. A klasszikus elvek jók, a hiba az alkalmazásban van. Major Máté: A magyar építészet harminc éve. Új Írás, 1975. 6.

${ }^{8}$ Az időszakról lásd részletesebben: Simon Mariann: Kötöttségek és kötődések. Identitáskeresés a hazai építészetben 1968-1972. Architectura Hungariae, 2000. 4.

http://arch.eptort.bme.hu/kortars8.html 
A modern építészet érett formájában számos problémát vetett fel, s ezek közül csak az egyik a külső megjelenés, illetve az abból fakadó jelleg kérdése. Jelen tanulmány témája éppen ez: a karakter keresése-értelmezése a hetvenes évek hazai építészetében. A bevezetőből már ismert, általános kérdésen túl - Szükségszerü-e a lakótelepek monotonitása, avagy lehet-e egyszerre emberi és modern építészetünk? - előbb-utóbb itthon is föl kellett tenni egy másik, ugyancsak általános kérdést: Szükséges-e, hogy sajátos arca, karaktere legyen a hazai építészetnek, s ha igen, honnan kell meríteni, milyen mintákat kell alapul venni, milyen módszerekre lehet támaszkodni? A helyi jelleg elvesztése feletti aggodalmak s az annak megőrzését célul kitüző regionalizmus gondolata végigkíséri a 20. század második felének nemzetközi építészetelméletét, a téma felvetése a hetvenes évek Magyarországán mégis kényes kérdésnek minősült. A helyi, netán nemzeti jelleg hangsúlyozása a kultúra bármely területén csak a ,szocialista hazafiság - proletár internacionalizmus" egyszerre teljesítendő követelményein belül, vagyis az aktuális elvárásoknak megfelelően volt lehetséges. Az építészek számára ezen túl külön nehézséget jelentett az ötvenes évek szocreál építészete, a szocialista tartalom és nemzeti forma jegyében felülről, politikailag megkívánt archaizálás ekkor még elevenen élő emléke. A hazai modern építészet történetében amúgy rövid közjáték a klasszikus modernizmus híveinek interpretációjában mitikus pokoljárássá vált, amelyet a hagyomány emlegetése bármikor újra előidézhetett. A fenti helyzet magyarázza, hogy amikor 1975-ben a kérdés - szükséges-e, hogy sajátos arca, karaktere legyen a hazai építészetnek? - a Tulipán-vitában először nyilvánosan elhangzott, a válaszok erősen szórtak. ${ }^{9}$ Voltak, akik úgy vélték, nincs szükség sajátosan magyar vagy akár csak hazai karakterü építészetre, voltak, akik azt mondták, hogy a karakternek az épület múvészi megoldásából kell fakadnia. S voltak, akik amellett álltak ki, hogy igen, kell, hogy legyen hazai, másokétól megkülönböztethető építészetünk.

Azok, akik ez utóbbi véleményen voltak, szinte kivétel nélkül a népi építészetet, a népmúvészetet nevezték meg mint azt az autentikus forrást, amelyből merítve a hazai építészet megújítható. A választás több okkal is magyarázható. Az egyik, hogy a modern építészetnek és a népi építészetnek az összekapcsolása, mint a sajátosan magyar építészet megteremtésének a záloga, az építész szakmának a századforduló óta vissza-visszatérő narratívája volt. A Lechner Ödönnel induló hagyományvonal a háború után előbb a szocreál beköszöntével merült fel mint lehetséges, de szükségszerüen elvetett alternatíva, majd annak múltával az 1957 és 1961 közötti, az építészeti hagyományról folytatott, de berekesztett vitákban. A hetvenes években újra visszatérő minta már két változatban jelent meg: Lechner Ödönt

\footnotetext{
${ }^{9}$ A Tulipán-vita az Élet és Irodalomban zajlott 1975. szeptember 27. és november 29. között. A témában felkérésre született további írásokat a Magyar Épitömüvészet 1976. 2. és 3. száma közölte.
} 
hol Meggyaszay István és Kós Károly, hol Lajta Béla és Kozma Lajos neve követte. ${ }^{10} \mathrm{~A}$ két sor egy tőről fakadó, mégis két különböző hagyományképet jelent: előbbi a népi építészet egyértelmű felhasználhatóságát állítja, utóbbi legfeljebb annak inspiratív szerepét fogadja el. Mindez átvezet a népi építészet választásának a hazai kultúra általános jellemzőiből következő magyarázatához. A magyar nemzeti fejlődés az úgynevezett kultúrnemzeti keretben zajlott le, aminek következménye az anyanyelv és a „népi” eredetü nemzeti karakter kiemelt kultúraképző szerepe. „A deskriptív jellegủ államnemzeti tagság felfogásával összehasonlítva az alapvetően preskriptív jellegü kultúrnemzeti tagság felfogását, a paradoxon abban van, hogy miközben az utóbbi sem törekszik másra, mint az előző, azaz az etnocentrikus örökség meghaladására és a nemzeti identitás tekintetében homogenizált társadalom megteremtésére, mégis arra kényszerül, hogy tagsági ideológiájában a természetességhez, a leszármazáshoz folyamodjon. Ennek oka, hogy a nemzeti lényeget másban, mint az anyanyelvben, az anyanyelv által konstituált kultúrában, illetve e nemzeti karakter által hiposztazált, ,népi' eredetű izlésben, illemben, szokásban, nem képes megtalálni." "11 A karakteres hazai építészethez a hagyomány felől közelítve így szükségszerűen jutunk el a népi építészethez mint a nemzeti identitás utolsó biztos szimbólumához. A népi építészet választásának harmadik oka abban keresendő, hogy a hetvenes évek Magyarországán különös figyelem kísérte a népmúvészetet. Népdalkörök és táncházak alakultak és múködtek, divat volt népi tárgyakat gyüjteni és népi ruhadarabokat viselni, s ebbe a - nem egészen politikamentes - divatba a laikusok számára is könnyű volt beilleszteni a népi építészetből megújuló modern építészet gondolatát. ${ }^{12}$

A példa, hogy a népművészetet nem csak a múltban, mint Lechner Ödön, hanem a jelenben is eredményesen fel lehet használni az építészetben, készen állt. Makovecz Imre neve és munkái a hetvenes években már nem csak szakmai körökben voltak ismertek. A fehér falú, nádfedésü vendéglátó épületeket a kritikusok rendre úgy sorolták be, mint olyan múveket, melyek a népi építészetből, de legalább abból is merítenek. ${ }^{13}$ Makovecz, aki folyamatosan tagadta, hogy ez igaz lenne, 1974-ben mégis tudatos népművészeti elemzésekbe kezdett. Az 1978-ban köz-

10 Az első névsort idézi például Berey Katalin: Nemzeti ihletésủ építészetet! Élet és Irodalom, 1975. október 25., az utóbbit Preisich Gábor: Modernség. Élet és Irodalom, 1975. november 8. és Gerő László: Vita az építészetről. Magyar Épitőmüvészet, 1976. 2.

${ }_{11}$ Csepeli György: Nemzet által homályosan. Századvég Kiadó, Budapest 1992. 23.

12 „Az új ellenzékiség első nagy fegyverpróbája 1972. március 15-e. Az amatőr színjátszó csoportok által gondosan előkészített ifjúsági tüntetés a $<$ Szegénylegények $>$ kosztümvilágában jelenik meg. Földig lógó kokárdák, nemzetőr karszalagok, fejre kötött, lelógó pántlikában folytatódó nemzetiszín szalagok. <Jancsózunk> mondják a résztvevők.” Szabó Miklós: 1972. Beszélő, 1998. 3.

${ }^{13}$ Mendele Ferenc: Megjegyzések a Sió csárdáról. Magyar Épitömüvészet, 1966. 4. - Kubinszky Mihály: A SZÖVTERV fiatal építészei. Magyar Épitömüvészet, 1970. 5. 
readott Napló, illetve az ugyanezen időszakban készült további írások azt bizonyítják, hogy a népmúvészetben azt találta meg, amit korábban másutt is keresett: egy mélyebb tudás, egy archaikus kultúra lenyomatát. „Úgy vélem, hogy az európai kultúra napja alatt egy titokzatos ősi kultúra alvilágának másik napja is ragyog. A kelet-európai népművészetben, kelta kísértetekben, ruhákban, dalokban nem nacionális, de népeket mindenképpen alkotni képes szellemiség él". ${ }^{14}$ A parajdi sárkányos minta így lett kőkori, kelta és szkíta mintákkal rokon, mint az ellentétek örök leképezése. A fekete-fehér, magas-mély formai dichotómiája könnyen továbbvihető az anyag és a szellem, a fogalom és az észlelet vagy épp a férfi-nő, az élet-halál elválasztó és egybekötő kettősségére, $\mathrm{s}$ Makovecz meg is tette ezt a lépést. „A síkbeli formák, kapcsolatok térbeli, imaginárius tartalmakat viselnek... Nem az elemi részek sokszorozása, hanem magasabb rendszerek osztódása adja az elemi részek értelmét." ${ }^{, 15}$ A népi építészeti elemek így nem pusztán tiszta formaképzésükkel, a népi építészet pedig egyszerü, logikus szerkesztésével lett példává, hanem a benne hordozott általános szimbolikus tartalmak által. A régi falusi háznak jelentése lett, melyben egyén és közösség szabályos, komoly rendje és értelmes kapcsolata fejeződött ki - egy valamikor volt egység. Ez az egység azonban tágabb összefüggésekből ered, hitelességét természettől adott volta igazolja. „Ha a tisztaszoba belső, individuális emelkedettséget valósít meg, milyen értelmes, és kimondom: csodálatos, hogy a ház oromzata és annak díszei, jelei egy még tágabb összefüggésrendszert, általában kozmikus összefüggéseket fejeznek ki. S a kozmikus jelek rendjét mutató oromzattal fordult a közösség felé, nem egyénieskedő arcot, hanem általános rendet kifejezve a családról, mely benne lakik" ${ }^{16}$ A népi építészet mintája általános jelként nyeri el értelmét, miközben valóságos elemként is megmarad. A két sík egymásra csúsztatható, de az indoklást mindig a ,látens szellemiség" adja. Egy 1977-es interjúban Makovecz Imre saját építészetét organikusnak és kanonikusnak nevezte, előbbihez mindjárt két értelmezést is füzve. „A meghatározásnak kettős értelme van, az egyik a Wright-i örökség, vagyis, hogy az épületnek organikusan kell a tájba illeszkednie". ${ }^{17}$ Az organikus építészet másik jelentése a ház belső lényegének kivetülése, az épület-lény antropomorfizmusa. Az emberi alkat vagy arc felépítését mintázó épületek az ember és az őt befogadó épület közötti mélyebb, általánosabb összefüggésekre utalnak. A farkasréti temető 1977ben készült ravatalozója ennek az antropomorf közelítésnek a kiváló példája. „Ennek a szúkülö barlangnak a belsejét úgy tervezte meg, hogy vele nyíltan a $<$ mellkas

\footnotetext{
${ }^{14}$ Előadás Kaposvárott 1977-ben. In: Makovecz Imre mühelye. (Szerk: Gerle János) Mundus Magyar Egyetemi Kiadó, Budapest 1996. 65.

15 Uo. 71.

${ }^{16}$ Makovecz Imre: Az apajpusztai példa. Müvészet, 1975. 8.

17 Látó házak. Frank János interjúja. Élet és Irodalom, 1977. november 12.
} 
csontjaira>, a bordákra utaljon. Nem a gótikus templom-hajó kőbordázata volt a mintája, hanem az anatómia. A ravatalozó bükkfából fürészelt bordái alá, a terem mellkasába fektetik a megbénult szívet, a halottat ... a $<$ szívburokban $>$, a saját $<$ minimális terében>, a koporsóban, urnában. Ez a szív, ez a páratlan testrész azonban már nem aszimmetrikusan helyezkedik el itt, hanem hossztengelyben. Az architektúra most felesel a bonctan törvényeivel. Mert ez pszeudoanatómia, az anatómia égi mása". ${ }^{18}$ A helyhez kötött organikus az általános organikus törvényében oldódott fel - s vesztette el helyi jellegét (1. és 2. kép).

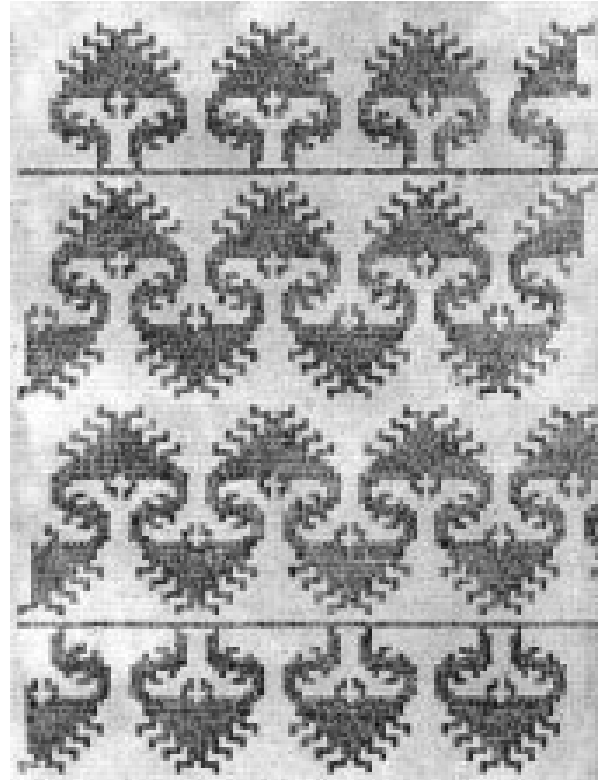

1. ábra. Parajdi sárkányos minta (Forrás: Malonyai Dezső: A magyar nép müvészete. Budapest, Franklin 1909. II. 252.)

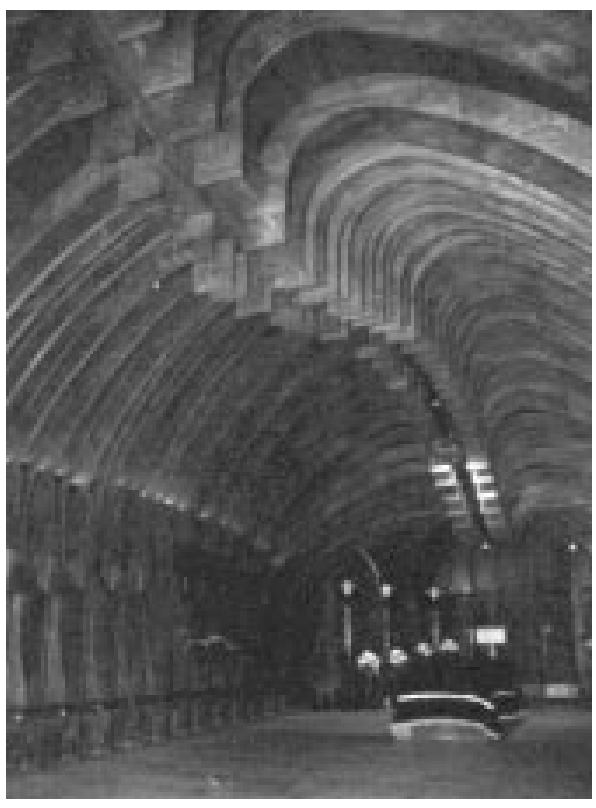

2. ábra. Budapest, Farkasréti temető ravatalozója. Makovecz Imre 1977

Makovecz Imrével ellentétben Csete György és a Pécs-csoport mindig is vállalta munkáiban a népi építészettel való rokonságot. A népi építészet eszköznek mutatkozott egy közösségi kultúra és egy humánus környezet megteremtéséhez is, amelyből kinőhet a sajátosan hazai építészeti karakter. „Kísérletünkben ezért nemcsak a kevesek által érthetőt, hanem olyan szociálisan értelmezett környezetet akartunk formálni, amely népünktől nem idegen, széles körben ismert alapokon nyugszik, a rendet és ezen belül a változatosságot is biztosítja. Ezért létrehozása-

\footnotetext{
${ }^{18}$ Frank János előszava. Makovecz Imre. Müterem-sorozat. Corvina Kiadó, Budapest 1980. 11.
} 
kor szándékosan fordultunk a népi kultúra humánus tartalmú forrásaihoz - az önmagában kevésnek érzett geometrikus gépi rend feloldására. Lehet, hogy a természettel még szervesen együtt élő népi szemlélet, tér- és tárgyalkotás és a szimbolikus díszítő múvészet választ adhat a természetet, humánumot hiányoló város kérdéseire? És hogy ezzel egy tájegységenként változó, országosan mégis összecsengő építészetet hozhatnánk létre?" ${ }^{19}$ - írták az építészek a paksi atomerőmü lakótelep házairól. A fenti értelmezésben a népi építészet a szervesség jelképe, amely az egyetlen közvetlen út a nemzeti, s az ezen túlmutató természeti lényeghez. A népi építészet olyan nemzetre szabott, sajátos hagyomány mint az anyanyelv, amelyet utódaink és őseink egyaránt értenek, amelyben „századok ösztönös és tudatos munkája eredményeként, ma is érvényes tanulságok és törvényszerüségek kristályosodtak ki”. ${ }^{20}$ Ez az anyanyelvként értelmezett építészet ekkor még egyszerre utal a folyamatosságra, a külső értékek asszimilációjára és az eredetre - utóbb a hangsúly egyértelműen a gyökerekre tevődik át. ${ }^{21}$ A népi építészet mint gyökér szervessége az ökológiai szervességgel cseng egybe, s épp ez az összefüggés kell, hogy hitelessé tegye. A népi építészetből és a természetből vett íves motívumok egy valamikor volt harmóniára, ember és természet összhangjára utalnak. „Az ARANYKOR házai, kazlai, dombjai, hegyei az ember és a természet harmóniájának tökéletes egységében élnek képzeletünkben. Amikor a föld fokozatosan emelkedő, majd ereszkedő kontúrú hajlékká növekszik, amikor minden emberközeli és természetes". ${ }^{22}$ A népi tulipán motívum ökológiai képletté válik, a kozmikus térrel, a szerves világgal biológiai egységben élő ember szimbólumává.

Mindkét előző példában hasonló, ha nem is azonos utat jártunk be. A népmúvészetből és az emberről, vagy a természetből vett minták hitelességét egy általánosabb, mélyebb szellemiséghez, illetve egy valamikor volt aranykor harmóniájához való kapcsolódás igazolta, a népi, a hazai minták kozmikus, elvont, általános jelekké váltak. Másként fogalmazva: hitelességüket az univerzálishoz való kapcsolódá-

19 Csete György, D. Blazsek Gyöngyvér, Deák László, Dulánszky Jenő, Jankovics Tibor, Kistelegdi István, Kovács Attila, Nyári József, Oltai Péter, Pálfi Miklósné: Kísérletünk Pakson. Élet és Irodalom, 1975. november 15.

${ }^{20}$ Csete György, Csete Ildikó, D. Blazsek Gyöngyvér, Deák László, Jankovics Tibor, Kistelegdi István, Oltai Péter: Anyanyelvünkön beszélünk-e építészetünkben? Müvészet, 1973. 9.

21 „Nem tudható, hogy a világ építészetének, ipar- és képzőművészetének levetett rongyaiból, kacatjaiból, hulladékaiból meddig lehet még ily kapkodva, büntetlenül cifrálkodni. Drágán vesszük ezt az olcsó kultúrát, kétszer fizetjük az árát, hiszen ha nem a mienk - úgy nem is becsüljük -, szemétre vetjük, ahová való. Nem maradiság tehát, hanem szükséges lépés, hogy figyelmünk végre a múzeumivá minősített épületek, tárgyak, tárgyrendszerek felé forduljon." Csete György: A juss. Importált klisék, vagy lehet-e a népnek építészete? Müvészet, 1980. 12.

${ }^{22}$ Csete György, Csete Ildikó, D. Blazsek Gyöngyvér, Deák László, Jankovics Tibor, Kistelegdi István, Oltai Péter: Anyanyelvünkön beszélünk-e építészetünkben? Müvészet, 1973. 9. 

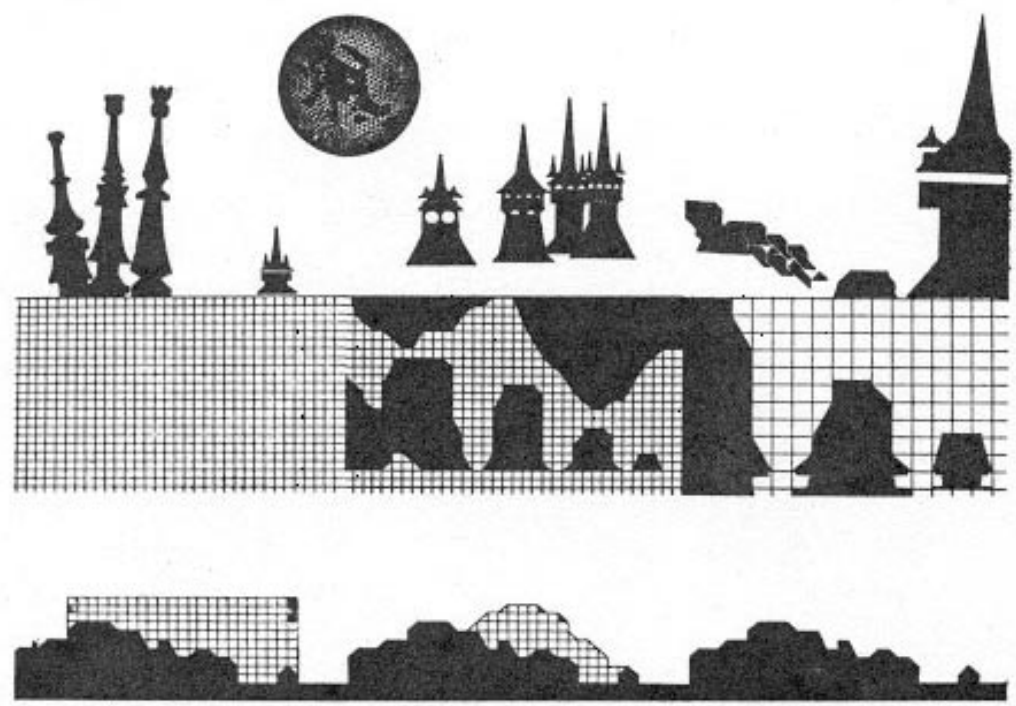

3. ábra. A raszterrács lebontása a táj és a település alkotóelemeinek szerves méret- és formarendjére. (Forrás: Csete György ábrája, Müvészet 1980. 12. 20.)

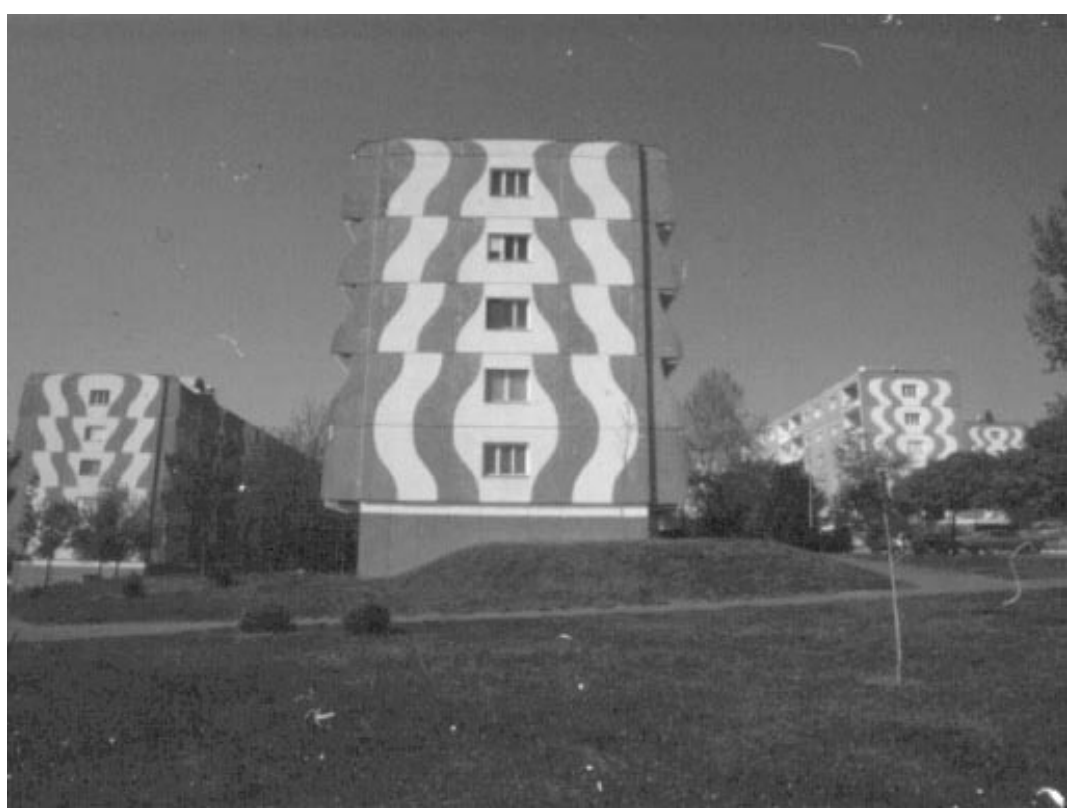

4. ábra. Paks, atomerőmủ lakótelep. Csete György, D. Blazsek Gyöngyvér, Deák László, Dulánszky Jenő, Jankovics Tibor, Kistelegdi István, Kovács Attila, Nyári József, Oltai Péter, Pálfi Miklósné 1975 
suk igazolta, a népi „egyszerüt” a benne fellelhető „ősegyszerü” lenyomata tette autentikussá (3. és 4. kép).

A karakteres építészet persze nem feltétlenül jelentette a nemzeti karakter keresését. A tízemeletes panelházak és sematikus középület társaik árnyékában már az is megkapónak tünt, ha egy épület nem nőtt olyan nagyra, esetleg követte a terepet, figyelt a környezetére és még közelebbről is voltak rajta élvezhető részletek. A léptékre, a helyre, az anyagokra figyelö építészetnek voltak példái külföldön is, nem ismeretlenek a hazai építészek előtt. A hetvenes évek építészei, ha külső vonatkoztatási pontokat kerestek, jól körülhatárolható körben mozogtak: a finn, az angol, a dán és a japán építészet volt a leggyakrabban emlegetett példa. ${ }^{23} \mathrm{~A}$ választás indoklása gyakran utalt az adott nemzet modern építészetének népi építészeti gyökereire, s különösen igaz volt ez a finn építészet esetében. ${ }^{24} \mathrm{~A}$ finn és az angol építészet saját számára mintaadó - igaz, a tízes években ható - szerepét Kós Károly is elismerte, ami akár kapocs is lehetett volna a finn vagy az angol és a hazai regionalizmus között. Az itthoni építészeti írásokban mégis inkább az „olyan finnes, dános, angolos az épület" típusú értékelések jelentek meg, mintsem a helyhez való alkalmazkodás elismerése. Pedig ezeknek az épületeknek a tervezői nem voltak teoretikus építészek, az inspiráló forrásokat talán még maguk előtt sem tisztázták, de biztos nem tették közzé, hogy a majdani elemzők dolgát megkönnyítsék. Kaszás Károly tihanyi ravatalozójáról azt írta kritikusa, hogy az ,alkotó az egyetemes és a magyar építészet hagyományait átélve, némiképpen a finn építészet eredményeit is hasznosítva jeles épületet hozott létre". ${ }^{25}$ Az épületelemzés érdekes módon az egyetemes és a helyi hagyományra hoz példát: előbbi a ravatalozóhoz felvezető dromosz és az azt lezáró kultuszhely együttese, utóbbi az attikacsatorna csónakot idéző formája, mint utalás a tihanyi halászatra. A tervező mindkét feltételezést kétkedve fogadta, a finn hatást viszont elismerte a fa rácsostartó szerkezeti kialakítá-

\footnotetext{
${ }^{23}$ Néhány példa a választásokra: Maros Tamás a japán építészetet, a dán Arne Jacobsent és az angol James Strilinget említi, mint számára meghatározó külföldi példát. Maros Tamás: Az épület, az építész és az építészet. Móser Zoltán interjúja. Valóság, 1976. 8. - A hetvenes évek közepén fiatal építészekkel készített interjúsorozat összefoglalásában a finn és az olasz építészet szerepel a leggyakrabban említett mintaként. Váriné Szilágyi Ibolya: Pályakezdő építészek szemlélete. Valóság, 1978. 6. - Csete György 1980-ban a dán, a finn, az angol és a japán építészet utánzását veti a hazai építészek szemére, miközben egy 1979-es körkérdés alapján azok mintaválasztása már a „nincs minta-hazai kortárs - klasszikus modern - bármi” körben szór. A posztmodern pluralizmus ekkor érte el hazánkat. Csete György: A juss. Importált klisék, vagy lehet-e a népnek építészete? Müvészet, 1980. 12. és Építészek felelnek. Mozgó Világ, 1979. 2.

${ }^{24}$ A finn építészethez füződő bensőséges kapcsolat magyarázata külön tanulmány tárgya lehetne. A hetvenes években élénk érdeklődéshez csak két adalék: 1976-ban a Fiatal Építészek Köre Finnországba (nyugati, de nem vízumköteles ország) tett tanulmányutat, s ugyanebben az évben jelent meg Nagy Elemér könyve Mai finn épitészet címmel.

${ }^{25}$ Dr. Istvánfi Gyula: Ravatalozó, Tihany. Magyar Épitömüvészet, 1978. 6.
} 
sában. ${ }^{26}$ Mennyire „finnes” ezek után az épület? A ravatalozó pontosan megválasztott helyen ül a domboldalon, egyszerre beengedi a természetet és megnyílik felé. Természetes anyagokat, követ és fát használ, láthatóan emberkéz által összeillesztve. Minden részlet ki van találva, végig van gondolva, miközben az egész épület egy tiszta, szinte tüntetően geometrikus szerkesztés eredménye. Ami átjött a finn építészetből, az a szemlélet, a természeti környezettel kialakított bensőséges kapcsolat és a természetes anyagok használata, a gondos részletképzés. Mindez csak a módszer, nem a minta közvetlen átvétele, hiszen ami létrejött, végül is tihanyi: a tihanyi bazalttufából emelt épület a tihanyi domboldalról néz a tihanyi belső tóra (5. és 6. kép).

A fenti, a részletekre és a helyre érzékeny szemléletet persze lehetett követni és a hazai viszonyokra alkalmazni (nem a tihanyi ravatalozó az egyetlen példa), de az itthoni adottságokat figyelembe véve, meglehetősen szük körben. Kicsi épületek és szegény megbízók kellettek hozzá, akik éppen korlátozott anyagi lehetőségeik miatt kénytelenek voltak a kézi munkára támaszkodni. Detájorientált tervezés határozták meg a jelenséget Reimholz Péter és Janáky István hetvenes évekbeli írásaikban, $\mathrm{s}$ helyette a telepítés-orientált tervezést ajánlották. ${ }^{27}$ Kiindulási pontjuk az volt, hogy Magyarországon az építőipar müszaki fejlettsége viszonylag alacsony szintü, vagyis a hazai építészek - legalább is a jellemző nagyobb méretü feladatoknál - hiú ábrándokat kergetnek, ha a nyugaton látott kifinomult technikai és részletmegoldásokat akarják követni. A részletek ugyanis azon túl, hogy a hazai körülmények között nem oldhatóak meg szépen, többnyire megkívánják az állandó változtatást is. „Az alakuló társadalmi igények - és velük párhuzamosan a haladó építészeti elvek - általában egyre magasabb dinamizmusú (flexibilitású, rugalmasságú, nyíltságú) épületstruktúrákat kívánnak: makrostruktúrákba behelyezhető épületstrukturális elemekből épülőket, elemekből növelhető és elemekkel módosítható halmazokat, minden részükben változékony szerkezeteket, sőt mobil szerkezeteket" ${ }^{28}$ A telepítés szempontja a szerkezet, a szerkesztés, az elrendezés elsődleges fontosságát jelenti, amely a keretet adja az elemek szabad mozgásának, változásának. A detáj és a telepítés-orientált tervezés párhuzamának a tárgy és a cselekvés-orientált szemlélet felel meg: „A tárgyakkal kapcsolatos viszony a szemlélődőtől a cselekvő, tevékeny viszony felé tolódik el. Az esztétikum forrása

${ }^{26}$ Beszélgetés Kaszás Károllyal 2001 februárjában.

${ }^{27}$ Janáky István - Reimholz Péter: Két tervezés. Előadás a MÉSZ-ben 1974. április 11-én. In: $A$ hely. Janáky István épületei, rajzai és írásai. Müszaki Könyvkiadó, Budapest 1999. - Reimholz Péter: Mozgások hatása az épített környezetre. Az egyik tervezés. Bercsényi 28-30. 1975. 2. - Janáky István: Két felfogás. Magyar Épitömüvészet, 1976. 2. - Janáky István: A negyedik mütípus. Bercsényi 28-30. 1977. 2. és Müvészet, 1977. 8.

${ }^{28}$ Janáky István - Reimholz Péter: Két tervezés. Előadás a MÉSZ-ben 1974. április 11-én. In: $A$ hely, i. m. 33 . 

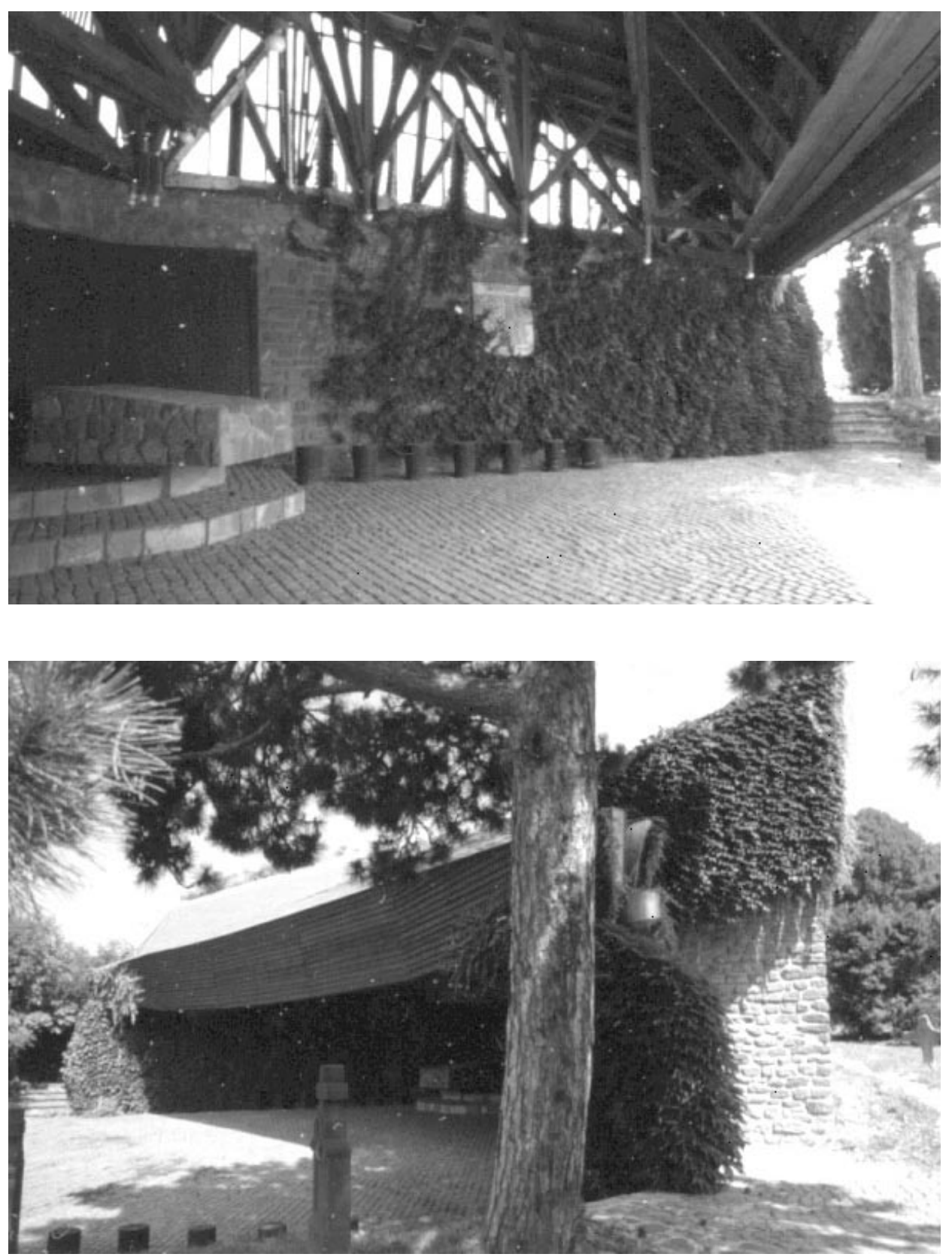

5. és 6. ábra. Tihany, ravatalozó

Kaszás Károly 1978 
a mozgó tárgyak és egyének mindenkor természetes, öntörvényüknek és szabad akaratuknak megfelelő rendszere, maga az élet, nem pedig a készen levő, készre csinált építőmúvészeti, tárgyformálási produktumok." ${ }^{29}$ A telepítés-orientáltság jegyében született épületek egyik példája a székesfehérvári Domus áruház, Reimholz Péter és Lázár Antal munkája. Az épület használata során felmerülő változó igényekkel számolva a tervezők a különböző mobilitású épületelemeket tartalmazó zónák tudatos szétválasztására törekedtek. A négy alrendszer - a strukturálisstatikai, a beépített alkatrészek, a mobil épületszerkezetek, illetve a berendezések zónája - eltérő építészeti megközelítést kívánt. Az elemek stabilitása és passzivitása a mobilitás igényének növekedésével csökken, de azonos rendszeren belül is eltérő megfogalmazásra lehet szükség. Az épület alapszerkezetének célja így kifele „tömeg és homlokzat vonatkozásában lehetőleg semleges elemként a környezet alkatrészévé válni, befele pedig - beton és acélszerkezet világos kettősségére építve fel önmagát beindítani az aktivitást sugárzó környezet kialakulásának a lehetőségét" ${ }^{30}$ (7. és 8 . kép).

A Domus áruházaknál és még néhány további, ekkor készült háznál alkalmazott módszer deklaráltan a hazai viszonyokból indult ki, az elmaradott technikai színvonalat és a szedett-vedett tárgyi környezetet alapul véve. „Az épületek egyre inkább hetedhét országból összesereglett tárgyak ... átjáróházai, és maguk is - egyre nyíltabban - determinált elemek ... montázsai ... Rendezettségük és rendetlenségük anatómiáját sajátos hazai cselekvés-szerkezetünk alakítja". ${ }^{31}$ A hazai alapokra figyelés célja a hazai építészet megteremtése volt, egy „a jelenleginél őszintébb, más országoktól különböző építészet" létrehozása. ${ }^{32}$ Ugyanakkor - bár a teória szerzői tagadták, hogy bármilyen előképet használtak volna ${ }^{33}$ - nyilvánvaló, hogy az építészeti strukturalizmus gondolataiból merítettek. Kaszás Károly tihanyi ravatalozóján finn hatást véltek felfedezni a kortársak, a székesfehérvári Domus áruházat bemutató kritikus az épületen ,a finn és a japán építészet új törekvéseinek tükröződését" érezte. ${ }^{34}$ A két, látszólag radikálisan különböző szellemben (a detáj, illetve a telepítés-orientáltság polaritásában) létrejött épület végül közös kategóriába került. S ez nem véletlen. A két épületben és az őket létrehozó szemléletben

${ }^{29}$ Reimholz Péter: Mozgások hatása ..., i. m.

30 Reimholz Péter: DOMUS Lakberendezési Áruház, Székesfehérvár. Magyar Épitőmüvészet, 1977. 1.

31 Janáky István: Két felfogás, i. $m$.

${ }^{32}$ Reimholz Péter: DOMUS Lakberendezési Áruház, i. $m$.

33 „Összefoglalva: a magyar építészet - elért eredményei ellenére - a háború óta és a szocreál után nehezen talál magára. Sajátos problémáink megoldásához nagyon kevés hagyomány és kortárs külföldi irányzat használható útmutatóként. Alkalmas tárgyi környezetet kell létesítenünk nagyrészt ismeretlen eszközökkel és módszerekkel." Janáky István és Reimholz Péter: Két tervezés. Előadás a MÉSZ-ben 1974. április 11-én. In: A hely, i. m. 35.

34 József Dénes: Gondolatok két Domus Áruházról. Magyar Épitőmüvészet, 1977. 1. 

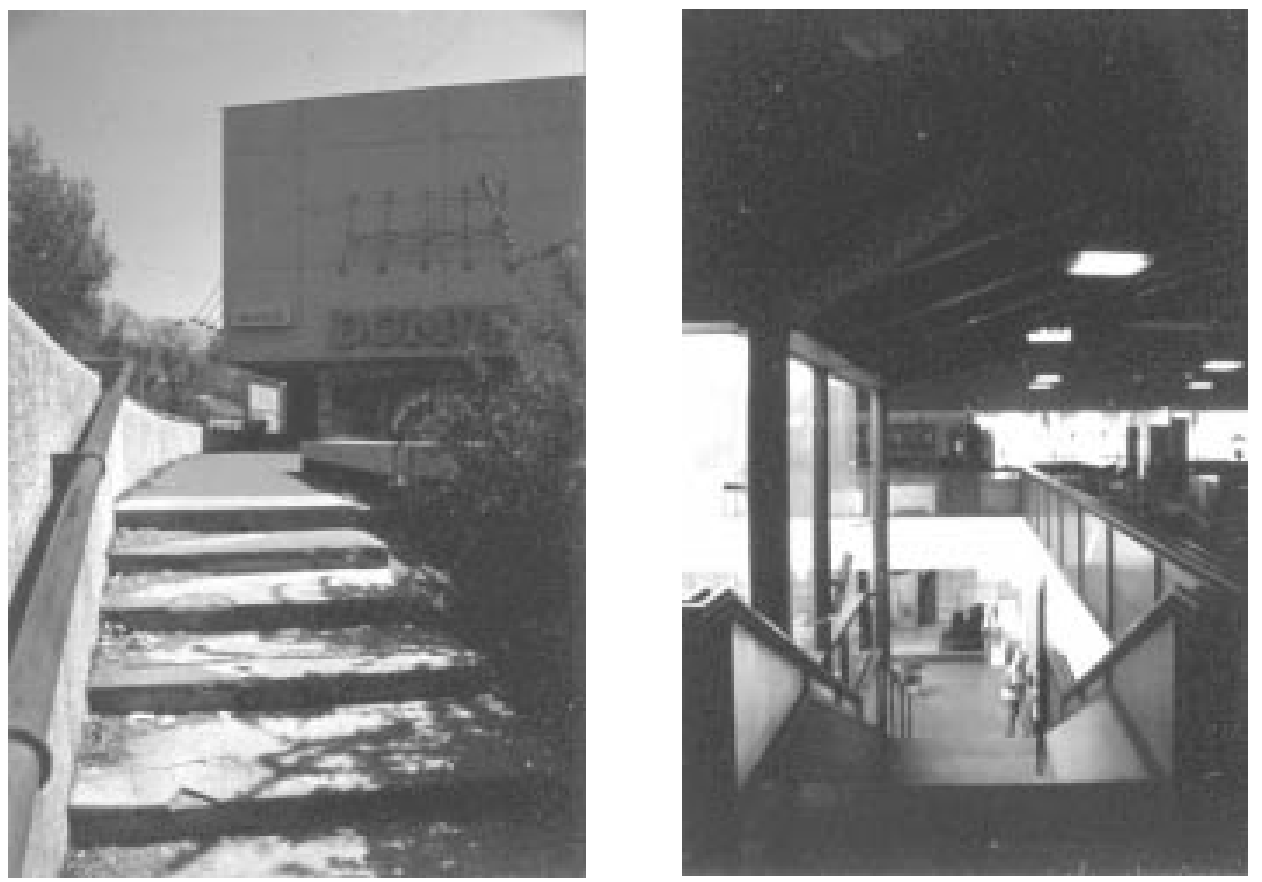

7. és 8. ábra. Székesfehérvár, Domus Áruház. Reimholz Péter és Lázár Antal 1975 (Fotó: Lukács Péter)

kétségtelenül közös, hogy mindkettőnél kimutatható a nemzetközi hatás - miközben a nemzetközi módszer ott, és ahogy alkalmazták, helyi, regionális megoldást eredményezett.

Az építészeti karakter keresése Magyarországon a hetvenes években két úton indult el. Az egyik irány a hazai jelleget keresve a hazai, elsősorban népi építészeti mintákból indult ki, miközben azok hitelességét kozmikus összefüggésekkel igazolta. A másik, többé-kevésbé tudatosan, nemzetközi példákat elemzett, s a szemléletet, a módszert alkalmazta a hazai viszonyokra. A kétirányú, ellentétes mozgás - hazaiból kozmikus, illetve nemzetköziből hazai - az építészeti karakter forrásának, egyben a kötődés tárgyának különböző meghatározásából ered. A hagyomány identitásképző szerepét hangsúlyozva szükségszerú egyrészt a jól megragadható szimbólumok használata, másrészt a gyökerek minél ősibb voltának bizonyítása. A helyhez kötődő identitást ugyanakkor nehezebb konkrét formai elemekre lefordítani. A hely kiterjedése változó (magyarországi, dunántúli, Balaton-felvidéki, esetleg tihanyi az épület), s a helyhez való viszonyunk, annak értelmezése is alakul. A hely szelleme a struktúrában és a részletekben lakozik, ami csak a képzet- 
tebb szemlélő számára nyílik meg könnyen, a megértésben általában az idő segít, amely utólag igazolja az épület beépülését környezetébe. A formai megjelenés felől közelítve ezért lettek a hetvenes évek helyre reflektáló épületei olyan „finnesek” vagy ,japánosak”. A hazai építészeti karakter forrását a szakma és a közvélemény ekkor még egyértelműen a hagyományban és nem a helyben kereste.

\section{PATTERNS AND METHODS. HUNGARIAN ARCHITECTURE AND CHARACTER IN THE SEVENTIES \\ Summary}

The general impression of Hungarian architecture in the seventies seems rather boring. However some tendencies emerged searching for alternatives and creating a characteristic Hungarian architecture within modernism.

The folk architectural tradition was only obvious authentic source of especially Hungarian architecture in the seventies both for experts and laymen. Imre Makovecz and György Csete followed this way. But their analysis of traditional forms and patterns turned into searching for general signs and symbols, authenticity of folk art was proved by its connection to the organic world, to "ancestral primitive". National patterns became cosmic signs. Some other architects turned to foreign lands for renewing national architecture; they concentrated on England, Finland, Denmark and Japan. Following of northern romantic modernism resulted in buildings made of local materials, adjusted to local scale and landscape. The other current tendency was the architectural structuralism whose representatives were just against loosing in detailing. This design method was based on the interaction of the flexible systems and the involved random things, as a perfect solution for the Hungarian reality, with its low standard building industry and mixed elements. International methods resulted in national solutions. The two opposite movements can be explained with the different interpretation of character: whether its source is in tradition or in place.

Keywords: architectural theory, Hungarian architecture, character 